\title{
Assessment of seasonal variation in water quality of Dal Lake (Kashmir, India) using multivariate statistical techniques
}

\author{
I. A. Najar \& A. Basheer \\ Department of Ecology and Environmental Sciences, \\ Pondicherry Central University, Puducherry, India
}

\begin{abstract}
Seasonal variation in surface water quality of Dal Lake was assessed using multivariate statistical techniques. Water quality data collected from 4 sampling sites during 4 seasons was analysed for 13 parameters. Significant variation $(\mathrm{p}<0.05)$ in temperature, $\mathrm{pH}, \mathrm{EC}, \mathrm{Ca}, \mathrm{Mg}, \mathrm{Na}, \mathrm{K}, \mathrm{DO}, \mathrm{BOD}_{5}, \mathrm{COD}, \mathrm{PO}_{4}-\mathrm{P}, \mathrm{NH}_{4}-$ $\mathrm{N}$ and $\mathrm{NO}_{3}-\mathrm{N}$ of sampling sites during different seasons was observed. Cluster analysis grouped 4 sampling sites during 4 seasons into three clusters of similar water quality as relatively less polluted (LP), medium polluted (MP) and highly polluted (HP) sites. The principal component analysis/factor analysis applied to extract and recognize the factors responsible for water quality variations in four seasons of the year resulted in three principal components for each season accounting for $75.78 \%, 83.25 \%, 87.33 \%$ and $78.96 \%$ of total variance for winter, spring, summer and autumn seasons respectively. Parameters like $\mathrm{NH}_{4}-\mathrm{N}, \mathrm{NO}_{3}$ $\mathrm{N}, \mathrm{BOD}_{5}$ and $\mathrm{COD}$ have strong positive loading whereas temperature and dissolved oxygen has strong negative loading. Thus, from the principal component/factor analysis it is clear that the domestic wastewaters, agricultural runoff and catchment geology play significant role in water quality variations in the Dal Lake for all the four seasons.

Keywords: agricultural runoff, catchment geology, cluster analysis, Dal Lake, factor analysis, Kashmir valley, principal component analysis, seasons, wastewaters, water quality.
\end{abstract}




\section{Introduction}

The quality of water at any point in a water body reflects several major influences, including the lithology of the basin, atmospheric inputs, climatic conditions and anthropogenic inputs [1]. Anthropogenic discharges constitute an invariable polluting source, while surface runoff is a seasonal phenomenon, largely affected by climate within the basin [2]. Seasonal variations in precipitation, surface run-off, ground water flow, interception and abstraction strongly affect lake volume and consequently the concentration of pollutants in a water body [3]. Human activities are major factors determining the quality of surface water through atmospheric pollution, effluent discharges, use of agricultural chemicals, eroded soils and land use [4]. These land use changes increase impervious surface resulting in storm runoff that negatively affect aquatic ecosystems and water quality [5]. Lentic systems with substantial agricultural and urban land use in their watersheds experience increased inputs and varying compositions of organic matter and nutrients mainly phosphates and nitrates from fertilizer application [6]. Hence monitoring is imperative for the sustainable management of these aquatic resources. However, with continuous monitoring generating a large and complex database of water quality [7], the application of multivariate analysis is a good technique for the interpretation of complex dataset as it allows a better understanding of the spatial variations in water quality [8].

The present study uses multivariate statistical techniques (cluster analysis, principal component analysis and factor analysis) to evaluate both similarity and differences in the physicochemical characteristics of water among the 4 basins of Dal Lake during four seasons, to discern water quality variables responsible for seasonal variation among them and to categorize them on the basis of pollution levels besides identifying the sources of pollution.

\section{Materials and methods}

\subsection{Study area}

Dal Lake, an urban lake situated towards the North-east of Srinagar, Kashmir, India, at an altitude of about 1,584 m above m.s.l, is tectonic in origin [9] and lies between $34^{\circ} 5^{\prime} \mathrm{N}$ and $34^{\circ} 9^{\prime} \mathrm{N}$ latitude and $74^{\circ} 50^{\prime} \mathrm{E}$ and $74^{\circ} 54^{\prime} \mathrm{E}$ longitude covering an area of about $11.50 \mathrm{~km}^{2}$. The lake is mainly fed by a large perennial inflow stream-Telbalnala, which drains the largest sub-catchment area of about $145 \mathrm{~km}^{2}$ and contributes around $80 \%$ of the total inflow into the lake [10], and a number of small streams viz., Peshpawnala, Shalimarnala, Merakhshanala, Harshikul situated around the shoreline besides the contribution from groundwater. The lake is divided into four basins: Hazratbal, Boddal, Nigeen and Gagribal (fig. 1). Nigeen basin is the deepest (maximum depth of about $6 \mathrm{~m}$ ) and Gagribal basin the shallowest (maximum depth $2.5 \mathrm{~m}$ ). The stream Telbalnala with other smaller streams enters the lake at Hazratbal basin. 


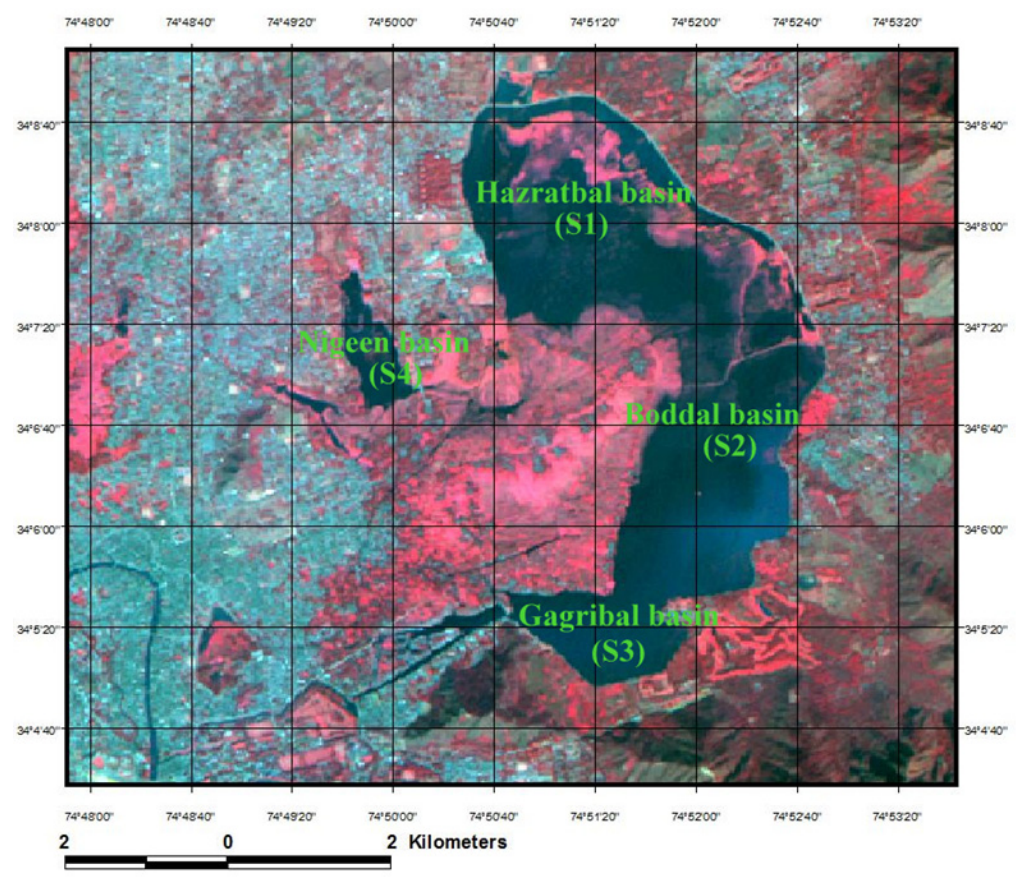

Figure 1: $\quad$ Outline map of Dal Lake showing sampling sites.

\subsubsection{Sample collection and chemical analysis}

Water samples were collected from the 4 sites- Hazratbal basin (S1), Boddal basin (S2), Gagribal basin (S3) and Nigeen basin (S4) every month during 20072009 and were kept in $1 \mathrm{~L}$ polyethylene plastic bottles which were prior cleaned with metal free soap, rinsed repeatedly with distilled water, soaked in $10 \%$ nitric acid for 24 hours and finally rinsed with ultrapure water. All water samples were stored in insulated cooler, taken on the same day to laboratory and kept at $4{ }^{\circ} \mathrm{C}$ till further processing and analysis [11]. Water temperature (T) was measured insitu during sample collection; $\mathrm{pH}$ and electrical conductivity (EC) were determined by $\mathrm{pH}$ meter and conductivity meter respectively. Calcium $(\mathrm{Ca})$ and magnesium $(\mathrm{Mg})$ concentrations were determined by the versenate method. Ammonical nitrogen $\left(\mathrm{NH}_{4}-\mathrm{N}\right)$ and nitrate nitrogen $\left(\mathrm{NO}_{3}-\mathrm{N}\right)$ was determined (spectrophotometer) by phenate method and phenyldisulphonic acid method respectively. Phosphate phosphorous $\left(\mathrm{PO}_{4}\right)$ was determined (spectrophotometer) by molybdate method. Dissolved oxygen content (DO) and biochemical oxygen demand $\left(\mathrm{BOD}_{5}\right)$ were determined using Winkler's method and chemical oxygen demand (COD) by dichromate method. Sodium (Na) and potassium (K) were analysed using flamephotometer. 


\subsubsection{Multivariate statistical methods}

With the objective of evaluating significant differences among the seasons and among the sites for all water quality variables, two-way analysis of variance (ANOVA) at $0.05 \%$ level of significance was applied [12]. Lake water quality data sets were subjected to three multivariate techniques- Cluster Analysis (CA), Principal Component Analysis (PCA) and Factor Analysis (FA) [13]. All statistical analyses were performed using SPSS statistical software (Version 16) and graphs were plotted by using Sigma Plot software (Version 11.0). BrayCurtis similarity was performed using PAST statistical software (Version 1.93).

Cluster analysis (CA) is a group of multivariate technique that classifies objects, so that each object is similar to the others in the cluster with respect to a predetermined selection criterion. Hierarchical agglomerative clustering is the most common approach, which provides intuitive similarity relationships between any one sample and the entire data set and is illustrated by a dendrogram, which provides a visual summary of the clustering processes, presenting a picture of the groups and their proximity, with a dramatic reduction in dimensionality of the original data [3].

Factor analysis (FA), which includes principal component analysis (PCA) is a technique applied to reduce the dimensionality of a dataset consisting of a large number of interrelated variables, while retaining as much as possible the variability presented in a dataset. This reduction is achieved by transforming the dataset into a new set of variables-the principal components (PCs), which are orthogonal (non-correlated) and are arranged in decreasing order of importance. Mathematically, the PCs are computed from covariance or other cross-product matrix, which describes the dispersion of the multiple measured parameters to obtain eigenvalues and eigenvectors. Principal components are the linear combinations of the original variables and the eigenvectors [14]. PCA can be used to reduce the variable numbers and explain the same amount of variance with fewer variables [15]. Factor analysis attempts to explain the correlation between the observations in terms of the underlying factors, which are not directly observable [16].

\section{Results and discussion}

\subsection{Water quality characteristics}

Physiochemical characteristics of water quality of the four sites (basins) of the Dal Lake during different seasons are given in fig. 2. The analysis of variance indicated significant variation $(\mathrm{p}<0.05)$ in temperature, $\mathrm{pH}, \mathrm{EC}, \mathrm{Ca}, \mathrm{Mg}, \mathrm{Na}, \mathrm{K}$, $\mathrm{DO}, \mathrm{BOD}_{5}, \mathrm{COD}, \mathrm{PO}_{4}-\mathrm{P}, \mathrm{NH}_{4}-\mathrm{N}$ and $\mathrm{NO}_{3}-\mathrm{N}$ among the sites and among the seasons. Alkaline nature of water recorded during summer is attributed to increase in photosynthetic activity resulting in more consumption of carbon dioxide and it corroborates with earlier reports [17]. EC varied from $0.10 \mathrm{mS} / \mathrm{cm}$ at S2 during summer to $0.26 \mathrm{mS} / \mathrm{cm}$ at $\mathrm{S} 1$ during autumn reflecting on the nutrient load of the lake. Low value of $\mathrm{PO}_{4}-\mathrm{P}(166.87,71.5,114.5$ and $114.2 \mu \mathrm{g} / \mathrm{l}), \mathrm{NO}_{3}-\mathrm{N}(198.42,147.5,150.2$ and $151.97 \mu \mathrm{g} / \mathrm{l})$ and $\mathrm{NH}_{4}-\mathrm{N}(287.07$, 

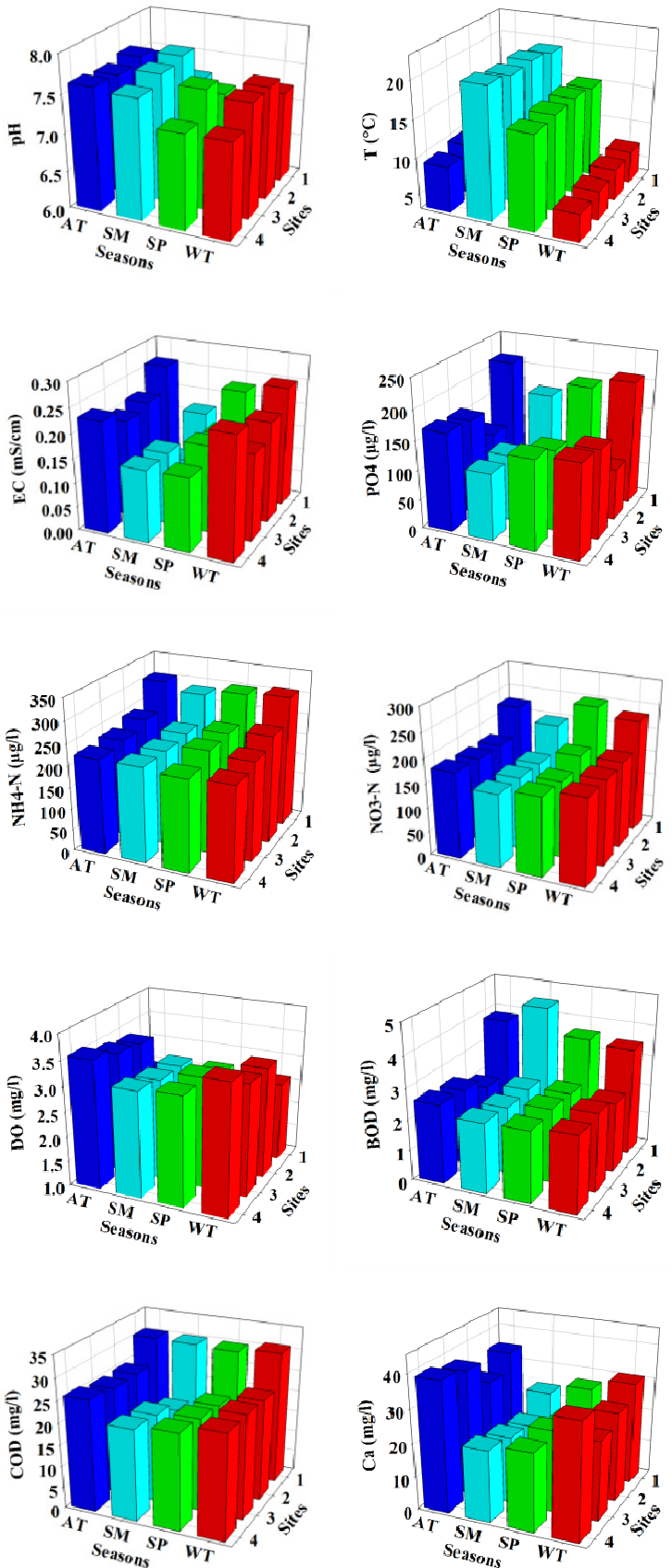

Figure 2: $\quad 3 \mathrm{D}$ graphs of physicochemical properties of water in the four basins (sites) of Dal Lake during different seasons. 

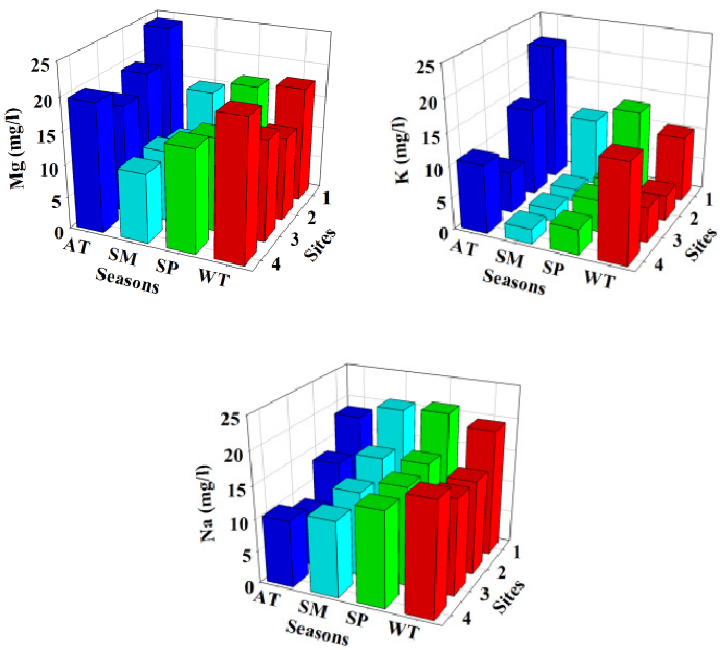

Figure 2: Continued.

227.33 and $221.1 \mu \mathrm{g} / \mathrm{l}$ ) at S1, S2, S3 and S4 respectively was observed during summer, except at $\mathrm{S} 4$ for $\mathrm{NH}_{4}-\mathrm{N}$ which was high during summer $(223.57 \mu \mathrm{g} / \mathrm{l})$. This is attributed to the release of wastewaters from house boats especially during summer. Low values of $\mathrm{EC}, \mathrm{PO}_{4}-\mathrm{P}, \mathrm{NH}_{4}-\mathrm{N}$ and $\mathrm{NO}_{3}-\mathrm{N}$ during summer could be attributed to the higher rate of assimilation by biota due to their peak growth [18]. $\mathrm{BOD}_{5}$ and $\mathrm{COD}$ ranged from $2.07 \mathrm{mg} / \mathrm{l}$ at $\mathrm{S} 2$ during autumn to $4.47 \mathrm{mg} / 1$ at S1 (Hazratbal basin) during summer and $18 \mathrm{mg} / 1$ at $\mathrm{S} 2$ during summer to $31 \mathrm{mg} / \mathrm{l}$ at $\mathrm{S} 1$ during winter respectively. This corroborates with previous findings where COD higher in Hazratbal basin is attributed to agricultural runoff and domestic wastewater it receives [19]. Ca concentration varied from $18.5 \mathrm{mg} / 1$ at S2 during summer to $38.97 \mathrm{mg} / 1$ at $\mathrm{S} 4$ during autumn. $\mathrm{Mg}$ and $\mathrm{K}$ concentrations varied from $9.67 \mathrm{mg} / \mathrm{l}$ and $2 \mathrm{mg} / \mathrm{l}$ at $\mathrm{S} 2$ during summer to $24.25 \mathrm{mg} / 1$ and $21.5 \mathrm{mg} / \mathrm{l}$ at $\mathrm{S} 1$ during autumn respectively. However $\mathrm{Na}$ concentration was low $(8.46 \mathrm{mg} / \mathrm{l})$ at $\mathrm{S} 3$ during autumn and was $21.24 \mathrm{mg} / \mathrm{l}$ at S1 during spring. Among these $\mathrm{Ca}$ is the most dominant cation which is attributed to the predominance of lime rich rocks in the catchment area [20].

\subsubsection{Cluster analysis}

Cluster analysis resulted in a dendrogram (fig. 3) grouping all the four sampling sites during four seasons into three statistically significant clusters. Since we used hierarchical agglomerative cluster analysis, the number of clusters is decided by water quality. Site DATS4, DATS3, DWTS4, DSPS4, DWTS3 and DSPS3 form cluster 1 which comprises low polluted sites (LP). Site DSPS2, DWTS2, DATS2, DSMS4, DSMS3 and DSMS2 forming cluster 2 correspond as moderately polluted sites (MP) that receive agricultural runoff. Cluster 3 (DSMS1, DWTS1, DATS1 and DSPS1) corresponds to highly polluted sites 
(HP), which receive domestic wastewaters, in addition to agricultural runoff. From the dendrogram it is clear that cluster 3 (Site 1) representing Hazratbal basin is the highly polluted basin of the Dal Lake during all the seasons, where as Nigeen and Gagribal basins (Site 3 and 4) are the least polluted ones. Boddal (Site 2) remains as a moderately polluted basin during all seasons. Though Gagribal (Site 3) and Nigeen (Site 4) remain as less polluted basins during spring, winter and autumn, they gets shifted to moderately polluted during summer (cluster 2). Since these two basins of the Dal Lake harbour the tourist house boats during peak summer tourist season, the release of waste water from these house boats results in higher pollution load of these basins during summer.

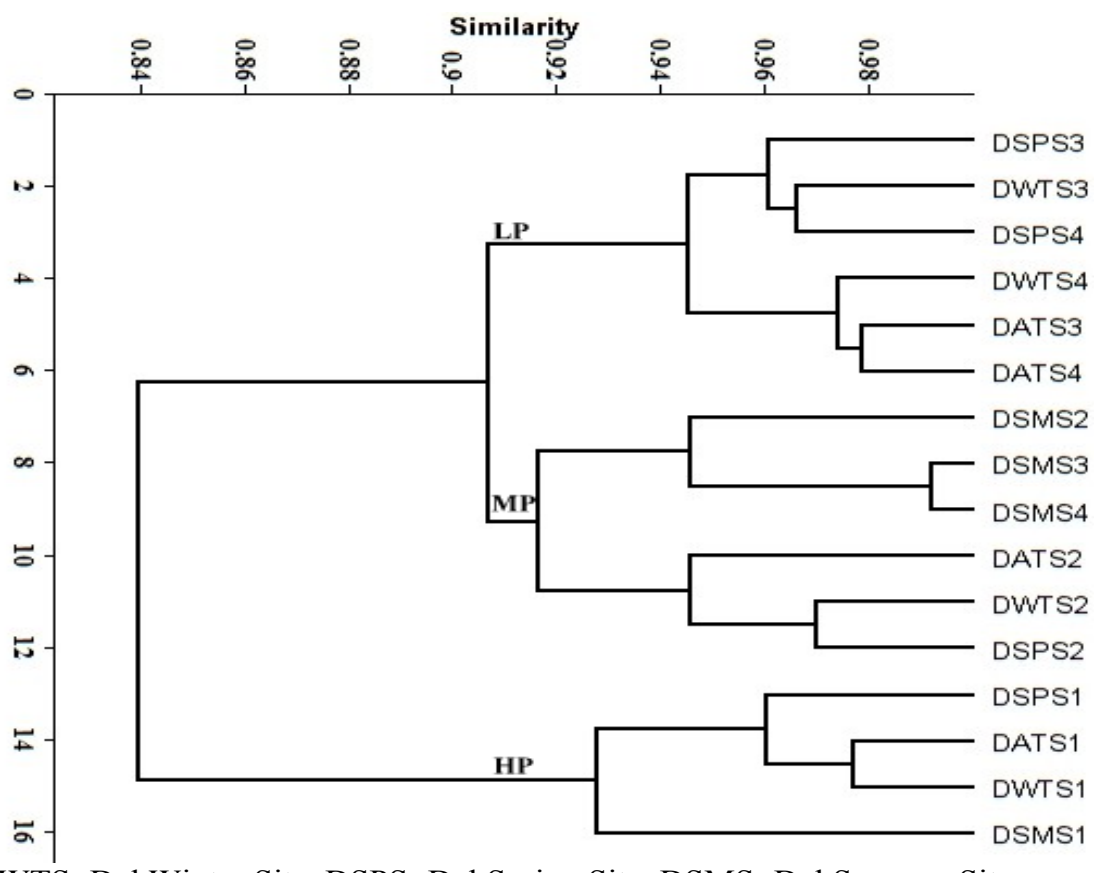

DWTS $=$ Dal Winter Site, DSPS=Dal Spring Site, DSMS=Dal Summer Site, DATS $=$ Dal Autumn Site, S1=Site1, S2=Site 2, S3=Site 3, S4=Site 4

Figure 3: Dendrogram of cluster analysis for sampling sites during different seasons based on the quality of surface water of Dal Lake.

\subsubsection{Principal component analysis/factor analysis}

Principal component analysis/factor analysis resulted in identification of significant water quality parameters. An eigenvalue greater than 1 considered significant [1] was taken as criterion for extraction of principal components required to explain the variance in the data. The different factors, total variance cumulative variance and component loadings for the three components derived from the PCA for different seasons are given in table 1. This analysis led to the 
explanation of $75.78 \%, 83.25 \%, 87.33 \%$ and $78.96 \%$ variance in case of winter, spring, summer and autumn respectively. Factor loadings were classified [21] as "strong," "moderate" and "weak," corresponding to absolute loading values of $>0.75,0.75-0.50$ and $0.50-0.30$, respectively.

Biplots $(1+2$ components $)$ of factor loading during different seasons are given in fig. 4. For the data set pertaining to winter season, among the three PCs, PC1 explaining $31.81 \%$ of the total variance has strong positive loading on $\mathrm{NH}_{4}-\mathrm{N}$, $\mathrm{BOD}_{5}, \mathrm{COD}, \mathrm{NO}_{3}-\mathrm{N}$ and strong negative loading on DO. PC1 signifies organic

Table 1: $\quad$ Seasonal factor loading values and explained variance of water quality of Dal Lake during different seasons.

Winter

\begin{tabular}{cccc}
\hline Parameter & PC1 & PC2 & PC3 \\
\hline $\mathrm{NH}_{4}-\mathrm{N}$ & 0.89 & -0.14 & 0.07 \\
$\mathrm{BOD}_{5}$ & 0.90 & -0.03 & 0.28 \\
$\mathrm{Ca}$ & 0.15 & -0.26 & 0.84 \\
$\mathrm{COD}$ & 0.81 & -0.35 & 0.36 \\
$\mathrm{DO}$ & -0.84 & 0.16 & 0.16 \\
$\mathrm{EC}$ & -0.01 & 0.87 & 0.01 \\
$\mathrm{~K}$ & -0.08 & 0.40 & 0.46 \\
$\mathrm{Mg}$ & -0.01 & 0.26 & 0.77 \\
$\mathrm{Na}$ & 0.39 & -0.35 & 0.70 \\
$\mathrm{NO}_{3}-\mathrm{N}$ & 0.80 & 0.48 & -0.03 \\
$\mathrm{pH}$ & -0.06 & -0.87 & 0.24 \\
$\mathrm{PO}_{4}$ & 0.53 & 0.54 & 0.17 \\
$\mathrm{~T}$ & 0.18 & -0.65 & 0.16 \\
Eigenvalues & 4.54 & 3.33 & 1.97 \\
Tot. vari. $(\%)$ & 31.81 & 25.44 & 18.51 \\
Cum. vari. (\%) & 31.81 & 57.26 & 75.78 \\
\hline
\end{tabular}

Summer

\begin{tabular}{cccc}
\hline Parameter & PC1 & PC2 & PC3 \\
\hline $\mathrm{NH}_{4}-\mathrm{N}$ & 0.95 & 0.18 & -0.10 \\
$\mathrm{BOD}_{5}$ & 0.91 & 0.31 & -0.00 \\
$\mathrm{Ca}$ & 0.05 & 0.85 & 0.41 \\
$\mathrm{COD}$ & 0.79 & 0.44 & 0.29 \\
$\mathrm{DO}$ & -0.97 & -0.17 & -0.03 \\
$\mathrm{EC}$ & 0.33 & 0.85 & -0.01 \\
$\mathrm{~K}$ & 0.86 & 0.24 & 0.16 \\
$\mathrm{Mg}$ & 0.77 & 0.02 & 0.39 \\
$\mathrm{Na}$ & 0.85 & 0.11 & 0.23 \\
$\mathrm{NO}_{3}-\mathrm{N}$ & 0.91 & 0.38 & 0.06 \\
pH & -0.25 & -0.76 & 0.01 \\
$\mathrm{PO}$ & 0.75 & 0.41 & -0.29 \\
$\mathrm{~T}$ & -0.12 & -0.14 & -0.96 \\
Eigenvalues & 8.32 & 1.73 & 1.29 \\
Tot. vari. $(\%)$ & 53.81 & 21.74 & 11.77 \\
Cum. vari. (\%) & 53.81 & 75.55 & 87.33 \\
\hline
\end{tabular}

Spring

\begin{tabular}{cccc}
\hline Parameter & PC1 & PC2 & PC3 \\
\hline $\mathrm{NH}_{4}-\mathrm{N}$ & 0.82 & 0.33 & 0.19 \\
$\mathrm{BOD}_{5}$ & 0.76 & 0.55 & 0.05 \\
$\mathrm{Ca}$ & 0.71 & -0.35 & 0.54 \\
$\mathrm{COD}$ & 0.88 & 0.29 & 0.14 \\
$\mathrm{DO}$ & -0.25 & -0.86 & 0.07 \\
$\mathrm{EC}$ & 0.12 & 0.51 & 0.72 \\
$\mathrm{~K}$ & 0.75 & 0.57 & 0.16 \\
$\mathrm{Mg}$ & 0.84 & 0.00 & 0.04 \\
$\mathrm{Na}$ & 0.94 & -0.13 & 0.19 \\
$\mathrm{NO}_{3}-\mathrm{N}$ & 0.47 & 0.77 & 0.09 \\
$\mathrm{pH}$ & 0.14 & -0.78 & -0.30 \\
$\mathrm{PO}$ & 0.02 & 0.73 & -0.10 \\
$\mathrm{~T}$ & -0.26 & 0.09 & -0.90 \\
Eigenvalues & 6.59 & 2.85 & 1.37 \\
Tot. vari. $\%$ ) & 39.5 & 29.11 & 14.62 \\
Cum. vari. (\%) & 39.5 & 68.62 & 83.25 \\
\hline
\end{tabular}

Autumn

\begin{tabular}{cccc}
\hline Parameter & PC1 & PC2 & PC3 \\
\hline $\mathrm{NH}_{4}-\mathrm{N}$ & 0.91 & 0.22 & 0.08 \\
$\mathrm{BOD}_{5}$ & 0.89 & 0.12 & 0.32 \\
$\mathrm{Ca}$ & 0.17 & -0.55 & 0.21 \\
$\mathrm{COD}$ & 0.83 & -0.03 & -0.29 \\
$\mathrm{DO}$ & -0.95 & -0.12 & 0.02 \\
$\mathrm{EC}$ & -0.05 & 0.80 & 0.01 \\
$\mathrm{~K}$ & 0.45 & 0.62 & -0.09 \\
$\mathrm{Mg}$ & 0.71 & 0.57 & 0.19 \\
$\mathrm{Na}$ & 0.41 & 0.81 & 0.00 \\
$\mathrm{NO}_{3}-\mathrm{N}$ & 0.79 & 0.26 & 0.44 \\
$\mathrm{pH}$ & -0.39 & -0.82 & -0.09 \\
$\mathrm{PO}_{4}$ & 0.62 & 0.04 & 0.62 \\
$\mathrm{~T}$ & 0.05 & 0.11 & -0.92 \\
Eigenvalues & 6.61 & 2.26 & 1.38 \\
Tot. vari. $\%$ ) & 41.03 & 24.61 & 13.31 \\
Cum. vari. (\%) & 41.03 & 65.64 & 78.96 \\
\hline
\end{tabular}

Tot. vari. $=$ Total variance, Cum. var. $=$ Cumulative variance. 
pollution from domestic wastewater [3]. PC2 explaining $25.44 \%$ of total variance has strong positive loading on $\mathrm{EC}$ and strong negative loading on $\mathrm{pH}$ and is attributed to the agricultural runoff $[22,23]$. PC3 explaining $18.51 \%$ of total variance has strong positive loading on $\mathrm{Ca}$ and $\mathrm{Mg}$, which are correlated with parent rock materials in the catchment area [24]. PC3 represents catchment geology. For spring season, among the three PCs, PC1 explaining 39.50\% of the total variance has strong positive loading on $\mathrm{NH}_{4}-\mathrm{N}, \mathrm{BOD}_{5}, \mathrm{COD}, \mathrm{K}, \mathrm{Mg}$, and $\mathrm{Na}$. PC1 represents organic pollution from domestic wastewater and agricultural runoff [25]. PC2 explaining $29.11 \%$ of total variance has a strong positive loading on $\mathrm{NO}_{3}-\mathrm{N}$ where as strong negative loading on $\mathrm{DO}$ and $\mathrm{pH}$. Positive loading of $\mathrm{NO}_{3}-\mathrm{N}$ results from conversion of $\mathrm{NH}_{4}-\mathrm{N}$ in presence of $\mathrm{DO}$, which further results in negative loading of DO [26]. Thus PC2 represents internitrogen conversion factor. PC3 explaining $14.62 \%$ of the total variance has strong negative loading on $\mathrm{T}$. The results corroborate the findings of Juahir et al [23] and PC3 represents physicochemical source of variation [27]. For summer season among the three PCs, PC1 explaining 53.81\% of the total variance has a strong positive loading on $\mathrm{NH}_{4}-\mathrm{N}, \mathrm{BOD}_{5}, \mathrm{COD}, \mathrm{K}, \mathrm{Mg}, \mathrm{Na}, \mathrm{NO}_{3}-\mathrm{N}$ and $\mathrm{PO}_{4}$ where as strong negative loading on DO. PC1 represents organic pollution from domestic wastewater and agricultural runoff [28]. PC2, explaining $21.74 \%$ of total variance has strong positive loading on $\mathrm{Ca}$ and $\mathrm{EC}$ where as strong negative loading on $\mathrm{pH}$. Positive loading on $\mathrm{Ca}$ and $\mathrm{EC}$ in $\mathrm{PC} 2$ has been associated with catchment geology [29]. PC3 explaining $11.77 \%$ of the total variance has strong negative loading on T. Negative loading of temperature during summer has been associated with physicochemical variation [24]. For autumn season, among the
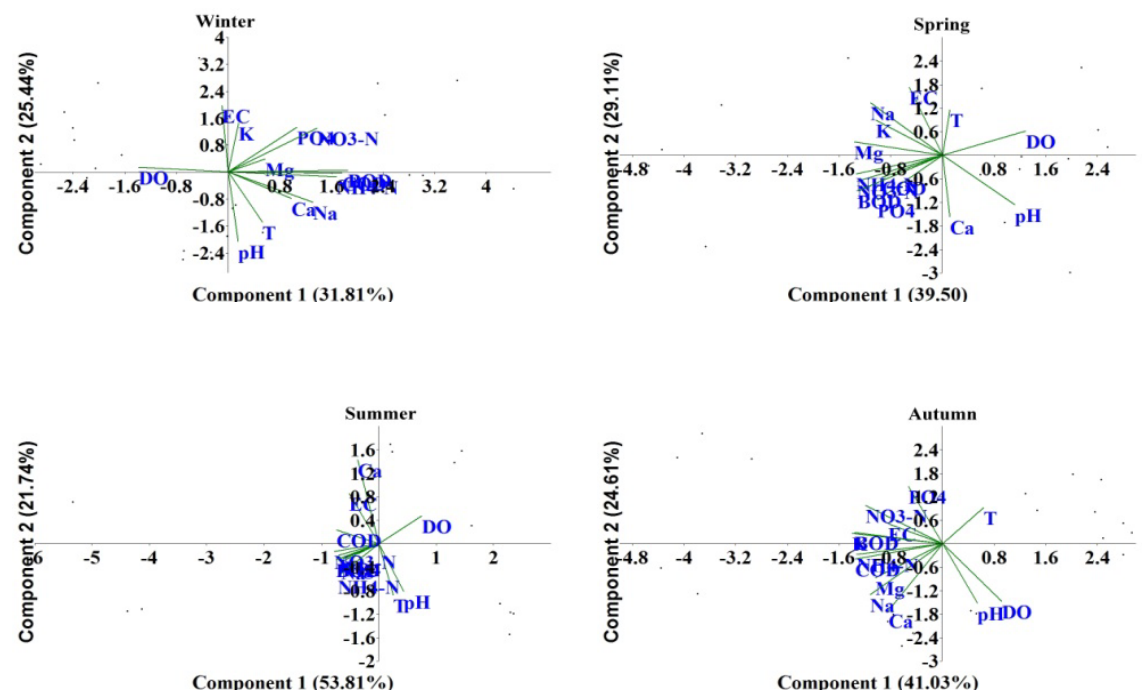

Figure 4: Biplots of factor loadings for each variable during different seasons. 
three PCs, the PC1 explaining $41.03 \%$ of the total variance has a strong positive loading on $\mathrm{NH}_{4}-\mathrm{N}, \mathrm{BOD}_{5}, \mathrm{COD}$ and $\mathrm{NO}_{3}-\mathrm{N}$, whereas strong negative loading on DO. PC1 represents organic pollution from wastewater [30]. PC2 is explaining $24.61 \%$ of total variance, has strong positive loading on $\mathrm{Na}$, EC and strong negative loading on $\mathrm{pH}$. Decomposing macrophytes have been linked with positive loading of $\mathrm{Na}$ and negative loading of $\mathrm{pH}$ [31]. Thus PC2 represents autochthonous factor. PC3, explaining $13.31 \%$ of total variance, has strong negative loading on $\mathrm{T}$. Negative loading of T during autumn has been associated with seasonal variation [32]. PC3 represents seasonal variation. Thus from the principal factor analysis/component it is clear that the organic pollution from domestic wastewaters, seasonal variation, agricultural runoff and catchment geology are significant factors that contributed to water quality variations in four seasons.

\section{Conclusion}

Hierarchical cluster analysis grouped four sampling sites during four seasons into three clusters (LP, MP and HP) with similar water quality features. Inputs from domestic wastewaters and agricultural runoff are mainly responsible for high pollution levels at Hazratbal basin. Boddal basin is moderately polluted whereas Nigeen and Gagribal basins are less polluted basins. PCA/FA identified latent factors as $\mathrm{NH}_{4}-\mathrm{N}, \mathrm{NO}_{3}-\mathrm{N}, \mathrm{BOD}_{5}, \mathrm{COD}, \mathrm{DO}$ and $\mathrm{T}$ explaining $75.78 \%$, $83.25 \%, 87.33 \%$ and $78.96 \%$ of total variance for winter, spring, summer and autumn seasons respectively, standing for domestic wastewaters, seasonal variation, agricultural runoff and catchment geology. Thus the existence of Dal Lake is threatened and implementation of environmental management plan for its restoration is warranted.

\section{References}

[1] Shrestha, S. \& Kazama, F., Assessment of surface water quality using multivariate statistical techniques: A case study of the Fuji river basin, Japan. Environmental Modelling and Software, 22, pp. 464-475, 2007.

[2] Najafpour, S., Alkarkhi, A.F.M., Kadir, M.O.A. \& Najafpour, G.D., Evaluation of spatial and temporal variation in river water quality. International Journal of Environmental Research, 2(4), pp. 349-358, 2008.

[3] Khadka, R.B. \& Khanal, A.B., Environmental Management Plan (EMP) for Melamchi water supply project, Nepal. Environmental Monitoring and Assessment, 146(1-3), pp. 225-234, 2008.

[4] Niemi, G.J., Devore, P., Detenbeck, N., Taylor, D. \& Lima, A., Overview of case Studies on recovery of aquatic systems from disturbance. Environmental Management, 14(5), pp. 571-587, 1990.

[5] Paul, M.J. \& Meyer, J.L., Streams in the urban landscape. Annual Review of Ecology and Systematics, 32(1), pp. 333-365, 2001. 
[6] Sickman, J.O., Zanoli, M.J. \& Mann, H.L., Effects of urbanization on organic carbon loads in the Sacramento river, California. Water Resources Research, 43, pp. 1-15, 2007.

[7] Zhang, Q., Li, Z., Zeng, G., Li, J., Fang, Y., Yuan, Q., Wang, Y. \& Ye, F., Assessment of surface water quality using multivariate statistical techniques in red soil hilly region: a case study of Xiangjiang watershed, China. Environmental Monitoring and Assessment, 152, pp. 123-131, 2009.

[8] Astel, A., Tsakovski, S., Simeonov, V., Reisenhofer, E., Piselli, S. \& Barbieri, P., Multivariate classification and modeling in surface water pollution estimation. Analytical and Bioanalytical Chemistry, 390(5), pp. 1283-1292, 2008.

[9] Jeelani, G. \& Shah, A.Q., Geochemical characteristics of water and sediment from the Dal Lake, Kashmir Himalaya: constraints on weathering and anthropogenic activity. Environmental Geology, 50, pp. 12-23, 2006.

[10] Trisal, C.L., Ecology and conservation of Dal Lake Kashmir. Water Resources Development, 3, pp. 44-54, 1987.

[11] APHA., Standard methods for the examination of water and wastewater, 21st edn., American Public Health Association: Washington DC, 2005.

[12] Zar, J.H., Biostatistical analysis, 5th. edn. Prentice Hall: Englewood Cliffs, New Jersey, 2009.

[13] Kazi, T.G., Arain, M.B., Jamali, M.K., Jalbani, N., Afridi, H.I., Sarfraz, R.A., Baig, J.A. \& Shah, A.Q., Assessment of water quality of polluted lake using multivariate Statistical techniques: A case study. Ecotoxicology and Environmental Safety, 72(20), pp. 301-309, 2009.

[14] Wunderlin, D.A., Diaz, M.P., Ame, M.V., Pesce, S.F., Hued, A.C. \& Bistoni, M.A., Pattern recognition techniques for the evaluation of spatial and temporal variations in water quality. A case study: Suquia river basin (Cordoba, Argentina). Water Resources, 35(12), pp. 2881-2894, 2001.

[15] Wu, M.L. \& Wang, Y.S., Using chemometrics to evaluate anthropogenic effects in Daya Bay, China. Estuarine Coastal and Shelf Science, 72(4), pp. 732-742, 2007.

[16] Yu, S.X., Shang, J.C., Zhao, J.S. \& Guo, H.C., Factor analysis and dynamics of water quality of the Songhua River Northeast China. Water Air and Soil Pollution, 144(1-4), pp. 159-169, 2003.

[17] Qadri, H \& Yousuf, A.R., Ecology of macrobenthos in Nigeen Lake. Journal of Research and Development, 4, pp. 59-65, 2004.

[18] Lu, Q., He, Z.L., Graetz, D.A., Stoffella, P.J. \& Yang, X., Phytoremediation to remove nutrients and improve eutrophic stormwaters using water lettuce (Pistia stratiotes L.). Environmental Science and Pollution Research, 17:84-96, 2010.

[19] Kundangar, M.R.D. \& Abubakr, A., Thirty years of Ecological Research on Dal Lake Kashmir. Journal of Research and Development, 4, pp. 4557, 2004. 
[20] Zutshi, D.P., Subla, B.A., Khan, M.A. \& Wanganeo, A., Comparative limnology on nine lakes of Jammu and Kashmir Himalayas. Hydrobiologia, 72, pp. 101-112, 1980.

[21] Liu, C.W., Lin, K.H. \& Kuo, Y.M., Application of factor analysis in the assessment of groundwater quality in a Blackfoot disease area in Taiwan. Science of the Total Environment. 313(1-3), pp. 77-89, 2003.

[22] Buck, O., Niyogi, D.K. \& Townsend, C.R., Scale-dependence of land use effects on water quality of streams in agricultural catchments. Environmental Pollution, 130, pp. 287-299, 2003.

[23] Juahir, H., Zain, S.M., Yusoff, M.K., Hanidza, T.I.T., Armi, A.S.M., Toriman, M.E., Mokhtar, M., Spatial water quality assessment of Langat River Basin (Malaysia) using environmetric techniques. Environmental Monitoring and Assessment, 173, pp. 625-641, 2011.

[24] Singh, K.P., Malik, A., Singh, V.K., Basant, N., Sinha, S., Multi-way modeling of hydro-chemical data of an alluvial river system-A case study. Analytica Chimica Acta, 571, pp. 248-259, 2006.

[25] Charkhabi1, A.H. \& Sakizadeh, M., Assessment of spatial variation of water quality parameters in the most polluted branch of the Anzali Wetland, Northern Iran. Polish Journal of Environmental Studies. 15(3), pp. 395-403, 2006.

[26] Boyd, C.E. \& Tucker, C.S., Pond aquaculture water quality management. Kluwer Academic Publishers: Boston, Massachusetts, pp. 700, 1998.

[27] Yang, Y.H., Zhou, F., Guo, H.C., Sheng, H., Liu, H., Dao, X. \& He, C.J., Analysis of spatial and temporal water pollution patterns in Lake Dianchi using multivariate statistical methods. Environmental Monitoring and Assessment, 170, pp. 407-416, 2010.

[28] Zhou, F., Guo, H.C. \& Liu, L., Quantitative identification and source apportionment of anthropogenic heavy metals in marine sediment of Hong Kong. Environmental Geology, 53(2), pp. 295-305, 2007.

[29] Khan, M.A., Shah, M.A., Mir, S.S., Suzana, B., The environmental status of a Kashmir Himalayan wetland game reserve: Aquatic plant communities and eco-restoration measures. Lakes and Reservoirs: Research and Management, 9(2), 125-132, 2004.

[30] Iscen, C.F., Emiroglu, O., Ilhan, S., Arslan, N., Yilmaz, V. \& Ahiska, S., Application of multivariate statistical techniques in the assessment of surface water quality in Uluabat Lake, Turkey. Environmental Monitoring and Assessment, 144, 269-276, 2008.

[31] Lim, D.S.S., Douglas, M.S.V. \& Smol, J.P., Limnology of 46 lakes and ponds on Banks Island, N.W.T., Canadian Arctic Archipelago. Hydrobiologia, 545, pp. 11-32, 2005.

[32] Konan, Y.M., Benjamin, Y.K., Albert, T. \& Bernard, S.M., Assessment of the Trophic Status of the Lagoon-bay of Tiagba in Cote d'Ivoire. Australian Journal of Basic and Applied Sciences, 4(8), pp. 4038-4045, 2010. 